ARTIGO ORIGINAL

ISSN 1677-5090

(C) 2019 Revista de Ciências Médicas e Biológicas

DOI: http://dx.doi.org/10.9771/cmbio.v1i1.34579

\title{
Evaluation of ibuprofen prescriptions into a Psychiatric Hospital: regarding safety, indication, and dose
}

\author{
Avaliação das prescrições de ibuprofeno em um hospital psiquiátrico: aspectos de \\ segurança, indicação e dose
}

Carolina Rosario Dantas ${ }^{1}$, Ricardo David Couto ${ }^{2}$, Denis de Melo Soares ${ }^{3 *}$

\begin{abstract}
${ }^{1}$ Graduated at Pharmacy from Universidade Federal da Bahia Master in Pharmacy from Universidade Federal da Bahia.; ${ }^{2}$ Graduated in Pharmacy and Biochemistry at Universidade Federal da Bahia.Master and Doctorate degrees in Pharmacy - Clinical and Toxicological Analysis at.; ${ }^{3}$ Graduated at Pharmacy and Byochemistry from Universidade de São Paulo. Master and doctorate degree at Medicine Faculty of Ribeirão Preto Pharmacology from Universidade de São Paulo
\end{abstract}

\begin{abstract}
Introduction: non-steroidal anti-inflammatory drugs (NSAIDs) such as ibuprofen are widely used throughout the world. In the psychiatric hospital, where this study was conducted, drugs such as selective serotonin reuptake inhibitors (SSRI) and lithium are widely used and may interact with ibuprofen (IBU). The literature also shows that ibuprofen may lead to changes in the central nervous system, which may trigger the imbalance of psychiatric disorders. Objective: to evaluate whether both the frequency of use and the prescriptions of ibuprofen are in agreement with the information contained in the literature regarding safety, indication, and dose. Methodology: retrospective observational cross-sectional study to evaluate the use of ibuprofen on patients from a psychiatric hospital. The prescriptions were evaluated for a 10-month period. Results: of the total number of prescriptions, 43 contained ibuprofen $600 \mathrm{mg}$. Note that in most cases, the drug was being prescribed according to the literature. However, in some cases there were divergences in the literature regarding: i) safety - information about the absence or presence of ulcers (1; 2.3\%), gastrointestinal events (0;0\%) and absence of dyspepsia, abdominal pain and discomfort gastrointestinal $(11 ; 25.5 \%)$ - ii) and the dose, in which in 19 cases (44\%) it was higher than recommended by the literature. In addition, in 2 prescriptions (4.7\%), the concomitant use of IBU and SSRI was observed and in 5 (11.6\%) of IBU and lithium. Conclusion: the use of this drug often escaped safety and dosage criteria concerning scientific literature.
\end{abstract}

Keywords: Ibuprofen. Usage Studies. Safety. Anti-inflammatory. Medication. Hospital pharmacy.

\begin{abstract}
Resumo
Introdução: os anti-inflamatórios não esteróides (AINEs), como o ibuprofeno, são amplamente utilizados no mundo todo. No hospital psiquiátrico em que este estudo foi realizado, medicamentos como inibidores seletivos da recaptação de serotonina e lítio são amplamente utilizados e sabe-se que podem interagir com o ibuprofeno. A literatura também mostra que o ibuprofeno pode levar a alterações no sistema nervoso central, o que pode desencadear o desequilíbrio dos distúrbios psiquiátricos. Objetivo: avaliar a frequência da utilização do ibuprofeno e se suas prescrições estão de acordo com as informações contidas na literatura com relação à segurança, indicação e dose. Metodologia: realizou-se um estudo transversal observacional retrospectivo para avaliar o uso de ibuprofeno em pacientes de um hospital psiquiátrico. As prescrições foram avaliadas por um período de 10 meses. Resultados: entre as 43 prescrições avaliadas, recomendou-se a dose de $600 \mathrm{mg}$. Foi observado que, na maioria dos casos, o medicamento estava sendo usado conforme prescrito na literatura. No entanto, em alguns casos houve divergências da literatura em relação a i) segurança informações sobre a ausência ou presença de úlceras (1;2,3\%), de eventos gastrointestinais (0;0\%) e ausência de dispepsia, dor abdominal e desconforto gastrointestinal $(11 ; 25,5 \%)$ - ii) dose, em que em 19 casos (44\%) foi maior do que o preconizado pela literatura. Além disso, em duas (4,7\%) prescrições, foi observado o uso concomitante de IBU e ISRS) e em cinco (11,6\%) de IBU e lítio. Conclusão: o uso desse medicamento frequentemente de modo geral não obedeceu aos critérios de segurança e dosagem referentes à literatura científica.
\end{abstract}

Palavras-chave: Ibuprofeno. Uso de medicamentos. Segurança do paciente. Anti-inflamatório. Medicamentos. Farmácia.

\section{INTRODUCTION}

NSAIDs are among the most widely used drugs in the world. They have analgesic, antipyretic, anti-inflammatory

Correspondente/ Corresponding: *Denis de Melo Soares - Faculdade de Farmácia, sala 6 - Universidade Federal da Bahia - End: Rua Barão do Jeremoabo, $\mathrm{n}^{\circ}$ 147, Ondina - Salvador, BA CEP: 40.170-115 - Tel: (71) 99113-5856-E-mail: denisms@ufba.br and antiplatelet properties that make them very attractive to both patients and prescribers ${ }^{1}$.

NSAIDs sales in Brazil reached million dollars values. For instance, in the state of Rio Grande do Sul, the rate of self-medication prevalence was found to be $53 \%$, with NSAIDs being the most widely consumed ${ }^{2}$.

In Brazil, many NSAIDs are available in local pharmacies, including ibuprofen (IBU), which is one of the med- 
icines sold without necessity of prescription. IBU inhibits both cyclooxygenase (COX) - 1 and COX-2 and conditions such as inflammation and pain ${ }^{3}$. Adverse reactions to the gastrointestinal, renal, and hepatic systems are the most commonly reported side effects. However, although rare, adverse psychiatric reactions may occur when the central nervous system (CNS) is affected 4 .

IBU interacts with various medications, including lithium and serotonin reuptake inhibitors (SSRIs) which are widely used in psychiatric institutions. Literature data also indicates that it can lead to changes in the CNS, which may trigger instances of psychiatric disorders.

The NSAIDs inhibits prostaglandins synthesis by cyclooxygenases blockage (COX1 and COX2). The decrease on prostaglandin levels fall leads to the reduction of renal arteries' flow by vasoconstriction, resulting in decreased glomerular filtrate and consequently decreasing renal lithium clearance. In parallel, theories postulate that low levels of prostaglandins can promote a direct rise in sodium and lithium, because lithium's renal reabsorption is similar to sodium's and because of the presence of several nephron proteins that promote both cations co-transportation ${ }^{5}$.

It has been shown that several SSRIs may impair both the platelet secretory response and the platelet aggregation induced by thrombin, collagen, and adenosine diphosphate and cause inhibition of platelet plug formation $^{6}$ therefore the association with IBU might worsen the platelet function.

Drug-use studies are useful and can have different goals'. These studies generally aim to obtain information about the prescription, dosage, standard of use, and clinical effects of particular drugs, thus reducing the risks associated with drug therapy and dispensing. They, therefore, contribute to the creation of new policies on the rational use of medicines.

The aim of our study is to evaluate if the prescriptions of ibuprofen are consistent with the information contained in the literature regarding safety, prescription, and dosage at the psychiatric hospital.

The study was approved by the Research Ethics Committee from the Nursing School of the Federal University of Bahia (UFBA), under the number ( $N^{\circ} 1.399 .812 / C A A E$ 51229615.9.0000.5531).

\section{METHODOLOGY}

A cross-sectional observational study of drug usage was done. Data was evaluated throughout 10 months, consistent with the period found in the literature for this type of study. The project was carried out at a psychiatric hospital, located in the state of Bahia. It is an institution of psychiatric care linked to the Brazilian Unified Health System. On average, in this institution, there is a monthly occupancy of 38 inpatients.

Explicit criteria for the use of ibuprofen has been previously identified through literature review, using primary evidence, as well as guidelines and the consensus of experts and organizations such as the Food and Drug Administration (FDA $)^{8,9}$ the Healthy Canadians ${ }^{10}$, the European Medicines Agency (EMA) ${ }^{11}$, the national institute for health and care excellence (NICE) ${ }^{12}$ and the Guideline from Dubois et al. ${ }^{13}$ (Figure 1). Inclusion criteria was Individuals that received a ibuprofen prescription, and Criteria for non-inclusion was individuals without ibuprofen prescription.

The medication dispensing was verified through hospitalized patient prescriptions, so the frequency was computed. An instrument was developed, tested and used to assess safety, indication, and dosage. The information was collected from the daily medical evaluations, medical diagnosis, nursing evaluations, and prescriptions. Dosage information was obtained through prescription.

We designed and performed a pilot test for two months to verify the internal consistency of the instrument.

The two months pilot study shows at least 38 inpatients a month, so the maximum number of inpatients at the final of 10 months would be 380 (380; 361 to 399). To estimate the sample size needed to find the number of cases with ibuprofen prescription, at a 95\% confidence level, we estimate the loss of $5 \%$, with an assumed rate of $15 \%$. The size was inflated $5 \%$ to compensate for the subject's loss. The returned find number was 43 cases. The sample size was calculated at the WinPepi version 11.65 , J.H.Abramson.

Data was stored in Microsoft Office Excel ${ }^{\circledR}$. The data was analyzed for ibuprofen information such as indication, the safety of appropriate or inadequate dose, and the frequency of use.

To assess safety, indication, and dose an instrument was developed, tested and used (Figure 1). 
Figure 1 - Stablished Criteria for the use of ibuprofen in patients hospitalized. *Non - steroidal anti-inflammatory drugs - NSAIDs; IBU - Ibuprofen; a) PPI - Proton pump inhibitor, b) ASA - acetylsalicylic acid

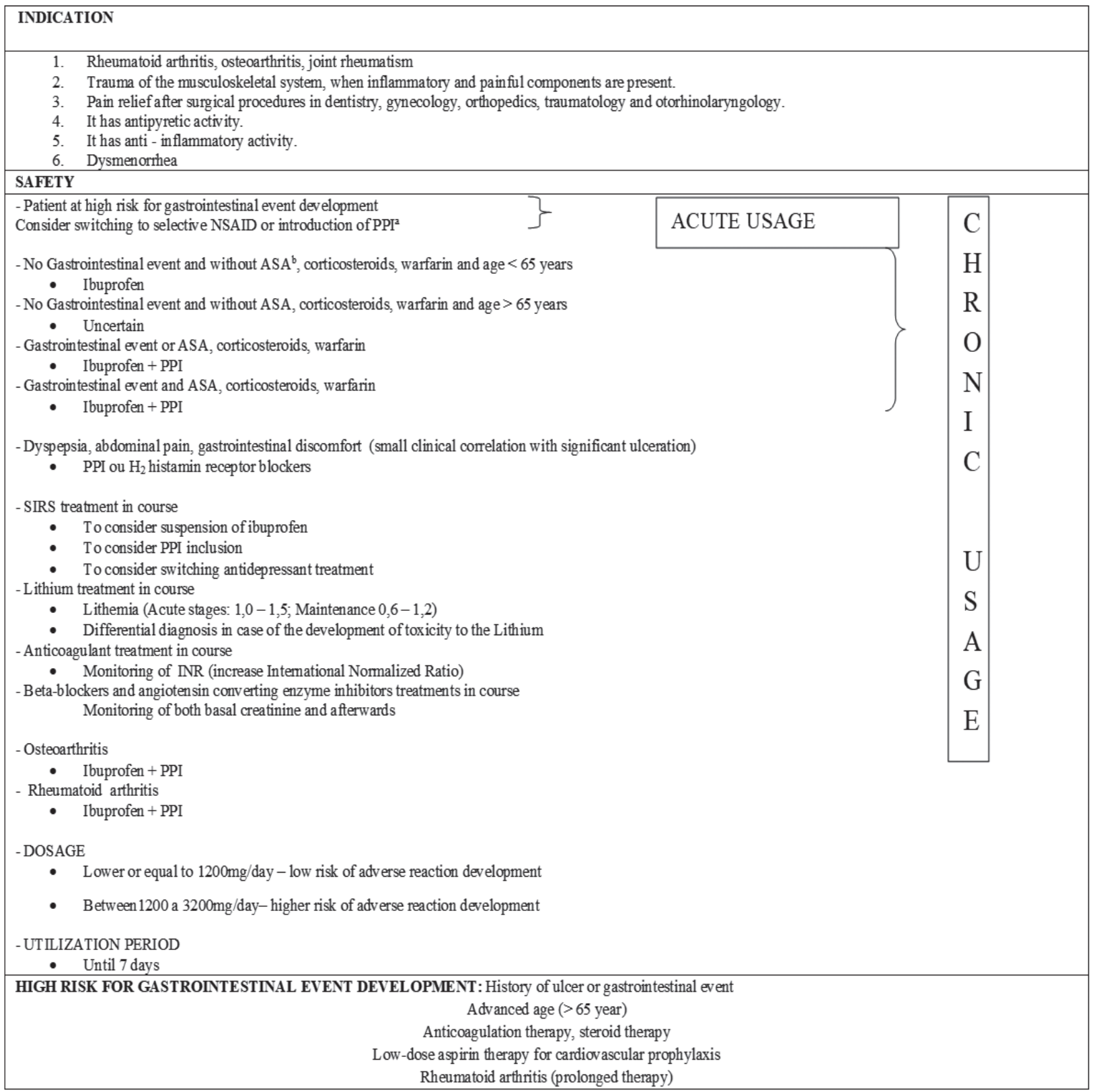

Source: Own authorship.

\section{RESULTS}

Altogether, there were 43 prescriptions, 25 individuals were male and 18 were female (Table 1). Regarding age, this varied between 21 a 58 years.

As for the prescribers, most were represented by physicians. However, as in HEAP there is dental care, the medication was often prescribed for tooth pain and tooth extraction, and the most prevalent indication was the prescription of IBU as a pain reliever and in no case has the use of the drug been reported to relieve pain from osteoarthritis and rheumatoid arthritis (Table 2, 3).
Table 1 - Ibuprofen prescription distribution in male and female

\begin{tabular}{lr}
\hline \multicolumn{1}{c}{ Sex } & $\mathbf{n ~ ( \% )}$ \\
\hline Female & $18(42)$ \\
Male & $25(58)$ \\
Total & $43(100)$ \\
\hline
\end{tabular}

Source: Research data 
Table 2 - Clinical indication of ibuprofen 600mg prescriptions

\begin{tabular}{lr}
\hline \multicolumn{1}{c}{$\begin{array}{c}\text { Clinical indication of ibuprofen } \\
\text { prescriptions }\end{array}$} & $\mathbf{n}(\%)$ \\
\hline Rheumatic processes & $0(0)$ \\
Trauma of the musculoskeletal system & $1(2)$ \\
Presence of inflammatory components & $4(9)$ \\
Presence of painful components & $24(56)$ \\
Presence of inflammatory and painful components & $3(7)$ \\
Dental procedure & $5(12)$ \\
Not reported & $6(14)$ \\
Total & $43(100)$ \\
\hline
\end{tabular}

Source: Research data.

Table 3-Percent of professionals prescribing ibuprofen $600 \mathrm{mg}$.

\begin{tabular}{lr}
\hline \multicolumn{1}{c}{ Professionals prescribing ibuprofen 600mg } & $\mathbf{n}(\%)$ \\
\hline Physicians & $28(65)$ \\
Dentistry & $15(35)$ \\
Total & $43(100)$ \\
\hline
\end{tabular}

Source: Research data.

In no case was the IBU being used as chronic therapy (> 1 month) and in 19 cases the dose was greater than $1200 \mathrm{mg}$ per day, but in most cases, this dose was less than or equal to $1200 \mathrm{mg}$ per day (Table 4).

Table 4 - Dose prescribed for ibuprofen greater than 1200mg perday.

\begin{tabular}{|c|c|}
\hline $\begin{array}{l}\text { Dose prescribed for ibuprofen greater than } \\
1200 \mathrm{mg} \text { per day }\end{array}$ & n (\%) \\
\hline Yes & $19(44)$ \\
\hline No & $22(51)$ \\
\hline Not reported & $2(5)$ \\
\hline Total & $43(100)$ \\
\hline
\end{tabular}

Source: Research data.

As for the risk factors for the development of gastrointestinal complications with the use of NSAIDs, no patient used the drug for more than a month during hospitalization, none was older than 65, none was using warfarin, corticosteroids or acetyl salicylic acid.

In only one case, there was information on the absence of ulcers in the chart. In the others, nothing was reported about the presence or absence of gastrointestinal events. As for dyspepsia, abdominal pain and gastrointestinal discomfort, there were 11 reports in the medical record by health professionals. In 31 cases it was not reported.

As for the occurrence of a gastrointestinal event, in only one case had the absence been described, and on an admission form from the city hall, in the other cases it was not reported.

Regarding the assessment of risk factors for cardiovascular disease, in 11 cases the risk factor for smoking was present, in 4 hypertension, in 1 hypercholesterolemia and among these cases, the prescribed dose was greater than $1200 m g$ per day.

In two prescriptions, the concomitant use of IBU and SSRI (citalopram) was observed. In five prescriptions, the concomitant use of IBU and lithium was observed. There were no records of litemia in two of these cases. No patient was using beta blockers and two were using angiotensin-converting enzyme (ACE inhibitors).

\section{DISCUSSION}

\section{Indication}

However, NSAIDs, according to Helin-Samilvaara et al. ${ }^{14}$ are more frequently used by elderly individuals and women. Fillingim e Gear ${ }^{15}$ suggest that men have a higher level of endogenous analgesic system activity compared to women.

IBU has relatively slow absorption, which may delay the onset of its analgesic effects. Despite this, it has analgesic efficacy and a profile benefit-risk that is more favorable when compared with other NSAIDs for use as an analgesic ${ }^{16}$.

The Food and Drug Administration ${ }^{6}$ indicate the use of ibuprofen for relief of temporary headache, muscular, lumbar, toothache, menstrual pain, for arthritis, primary dysmenorrhea and temporary use as antipyretic. The Australian Department of Health (2013) ${ }^{16}$ adds the indication of its use for neuralgia, sore throat, colds and flu.

In our study, IBU was most prescribed as an analgesic (Table 2). Thus, the indication did not vary from what the literature guides recommend ${ }^{12,16}$. However, in six cases the indication was not reported.

It is important to determine if the pain is related only to physical or psychic conditions. Pain is subjective and its perception depends on the psychological state of the individual ${ }^{17}$. In this context, anxiety and depression can raise the perception of pain. Nevertheless, in the present study the reason for the pain was attributed only to physical conditions and in no case was it related to the psychic condition of the individuals, nor was it described as potentiated by this psychic condition.

Most of the prescribers were physicians, however, dentists also prescribed it for odontalgia and exodontia (Table 3). We have seen that dentists prescribed IBU after dental procedures. Al-Khateeb et al. ${ }^{18}$ showed that patients experienced pain after a simple tooth extraction. They then recommend that dentists consider prescribing analgesics during the first week after tooth extraction.

\section{Dose}

The FDA (2015) suggests that although IBU is the safest among NSAIDs, there appears to be a dose-related risk for gastrointestinal and renal adverse events. However, at doses up to $1200 \mathrm{mg}$ per day, these risks appear to be lower although it is common to find doses up to $3200 \mathrm{mg}$ per day ${ }^{8}$. 
IBU has a maximum recommended dose of $1200 \mathrm{mg}$ per day and when used in high doses $12400 \mathrm{mg}$ or more per day), it increases the risk of heart attack and stroke ${ }^{10}$.

The EMA reinforces these warnings, including the recommendation that doses of 2400mg per day should not be used in patients with a history of heart disease (ischemic heart disease, congestive heart failure) and stroke, or who exhibit risk factors for cardiovascular disease. Risk factors include, but are not limited to, smoking, diabetes, hypertension, hypercholesterolemia, and a family history of cardiovascular disease ${ }^{8}$. The orientations from Health Canada $^{10}, F A^{9}$ e EMA ${ }^{11}$ were considered and also established a safe dose of $1200 \mathrm{mg}$ per day.

Most cases this dose was less than or equal to $1200 \mathrm{mg}$ per day. However, in no case was the drug used to reduce the pain caused by osteoarthritis or rheumatoid arthritis, which could in some way justify a dose greater than $1200 \mathrm{mg}^{10,11}$. Regarding the evaluation of heart disease history, in only one case it was reported, and in some cases, the risk factors were described.

The wide use of ibuprofen (22\% of the total NSAID use $)^{19}$ is usually because it is considered a very safe drug 8,12 . It has been shown that IBU increases the risk of cardiac arrest by $31 \%$. The risk is high for those who already have some cardiovascular diseases, such as hypertension ${ }^{19}$.

\section{Safety}

The European Medicines Agency ${ }^{10}$ and the Health Canada $^{11}$ report that there is an increased risk of cardiovascular events when IBU is used for a period longer than seven days and recommend use for a short period (less than 7 days). The period defined in this study and based on the literature, as a rationale for the use of this medicine was seven days ${ }^{8}$. In 10 cases, among the 43 evaluated, the duration of treatment was higher than recommended.

When prescribing NSAIDs, prescribers should take precautions based on the patient's risk. Severe complications in the gastrointestinal tract occur in 1\% to $4 \%$ of NSAID users annually ${ }^{20}$. It involves the inhibition of COX 1 and consequently, the lack of prostaglandin's gastroprotection. Symptomatic or complicated ulcers (with hemorrhage, perforation or obstruction) are the most serious gastrointestinal side effects ${ }^{21}$.

Laine ${ }^{22}$ classified as high-risk individuals to develop gastrointestinal problems those with a history of ulcer or gastrointestinal events, advanced age (> 65 years), anticoagulation therapy, corticosteroid therapy, and ASA therapy, as well as treatment with NSAIDs for pathologies such as rhe umatoid arthritis. The same author points out that, in these patients, both the use of selective NSAIDs and co-therapy with a PPI should be considered.

Wilcox et al. ${ }^{23}$ argues that, among non-selective NSAIDs, data indicates that gastrointestinal safety may be greater with IBU at a dose of $1200 \mathrm{mg}$ per day or less, however for patients classified as high-risk individuals, the indications correspond to those described by Laine ${ }^{22}$.
Dubois et al. ${ }^{13}$ reviewed the use of NSAIDs, including those that specifically inhibit COX-2, in addition to the use of PPI co-therapy in patients requiring chronic anti-inflammatory therapy (> 1 month). For patients without previous gastrointestinal events (gastrointestinal ulcers, bleeding, perforation or obstruction) and the use of ASA, warfarin or corticosteroid (classified as low risk), the use of non-selective NSAIDs was only scored as indicated for those with age less than 65 years $^{13}$ (Figure 1).

For patients over 65 years of age and with low risk, the choice between the use of non - selective NSAIDs or specific COX-2 selective inhibitors was reported as uncertain. For patients with previous gastrointestinal events or concomitantly using ASA, warfarin or corticosteroids, the use of a COX-2 selective inhibitor or non-selective NSAIDs with PPIs has been reported as indicated. Finally, for patients with previous gastrointestinal events and in use of ASA, warfarin or corticosteroids, a PPI should be used concomitantly with non-selective NSAIDs or a selective COX-2 inhibitor (figure 1) $)^{13}$

When NSAIDs are combined with anticoagulants, there is a significant increase in bleeding, which can increase International Normalized Ratio (INR) by as much as 15 percent. Therefore, when it is necessary to initiate NSAIDs therapy in individuals using anticoagulants, there should be adequate monitoring of the INR, as well as the dose adjustments of warfarin ${ }^{24}$. In the present study, no patient was using IBU for more than one month, none were older than 65 years, and none were using warfarin, corticosteroids or ASA. In only one of the medical records, the absence of a gastrointestinal event was reported, in all the other cases this was not reported.

When the patient presents dyspepsia, abdominal pain, gastrointestinal discomfort, the use of PPIs or histamine $\mathrm{H}_{2}$ receptor blockers is indicated as therapeutic or preventive measures. In the cases dyspepsia reported, with 2 of PPI use and 1 case of histamine $\mathrm{H}_{2}$ receptor antagonist $^{19}$.

COX-2 participates in the production of renal prostaglandin and all NSAIDs can cause renal failure. Some medications, such as beta-blockers and angiotensin-converting enzyme inhibitors may increase renal complications when used concomitantly with NSAIDs ${ }^{19}$. Specialists propose the monitoring of renal function after the initiation of NSAIDs in individuals using these drugs ${ }^{25}$. There was no patient using beta-blockers, but two were using angiotensin-converting enzyme inhibitors. However, it is important to infer that renal function was evaluated neither before nor during the therapy of these patients.

A meta-analysis, conducted in 2008 with observational studies, showed a significant increase in the risk of gastrointestinal bleeding after the use of SSRIs and NSAIDs concomitantly ${ }^{26}$.

The hypothesis for the mechanism of drug interaction is that serotonin is important for the maintenance of platelet hemostatic function such as platelet aggregation. SSRIs inhibit their uptake by platelets, impairing platelet 
aggregation and thus increasing the risk of gastrointestinal bleeding ${ }^{26}$.

It is important to note that no guideline has been found to warn against the concomitant use of these drugs. Regulatory agencies need to review existing documents and highlight the magnitude and strength of the risks for this interaction. The symptoms may present as hematemesis or melena ${ }^{26}$.

Suspension of NSAIDs, concomitant treatment with PPI or switching to another antidepressant should be considered in patients receiving SSRIS and NSAIDs simultaneously ${ }^{26}$.

Concomitant use of IBU and SSRIs (citalopram) was observed in two prescriptions. In these two cases, no hematemesis or melena occurred. It was not described by the multi-professional team if the i) suspension of IBU ii) beginning of a PPI or iii) changing to another antidepressant was considered.

IBU interacts with lithium, which is the first line of treatment for bipolar mood disorders, decreasing its elimination and raising blood levels in individuals with normal renal function, and therefore, the risk of toxicity ${ }^{27}$.

Hassan et al. ${ }^{28}$ reported a case in which one man, 26 years old, diagnosed with bipolar mood disorder and schizophrenia using lithium, presented confusion, dysarthria, abnormal gait, and diarrhea two days after the dental prescription of IBU due to dental extraction with dosage of $800 \mathrm{mg}$, three times a day. In the emergency department, laboratory values were significantly elevated to the lithium level $(3 \mathrm{mmol} / \mathrm{L})$, with moderate renal insufficiency (serum creatinine of $1.6 \mathrm{mg} / \mathrm{dL}$ ) secondary to dehydration.

In a publication of the National Institute for Health and Care Excellence (NICE) Service ${ }^{12}$, pharmacists in public services when conducting a lithium-based patient support program planned to advise an individual on lithium interactions with NSAIDs. A patient on a prescription of lithium and IBU was immediately included in the counseling program.

Clinicians should consider the use of NSAIDs in the differential diagnosis of lithium toxicity, monitor serum lithium concentrations of patients during initiation or discontinuation of therapy with Cyclooxygenase Inhibitors ${ }^{29}$.

Among the prescriptions in which the concomitant use of lithium was observed, in two there were no records of lithemia. In no case was there reporting of toxicity with this use, thus, there was no differential diagnosis for drug interaction.

\section{Ibuprofen and CNS}

Results from our group and others demonstrate that $I B U$ acts via a mechanism independent of COX-1 and COX-2 blockade to induce antipyresis. This mechanism is dependent on the activation of vasopressin $V 1$ receptors in the $\mathrm{CNS}^{30}$, by increasing vasopressin levels in the ventral septal region ${ }^{31}$. In addition to being a natural antipyretic, this neurotransmitter plays an important role in the CNS, regulating sexual behavior, aggression, fear, stress, as well as learning and memory processes ${ }^{32}$.

Elevated levels of vasopressin are related to elevated sexual activity, as well as to a deregulation of behavior, leading to aggression, by inhibiting the synthesis of serotonin. Its performance also interferes with learning, memory, and cognition ${ }^{32}$.

Therefore, it is possible to speculate that, by acting on neurotransmitters regulation such as vasopressin, and therefore on brain activity, IBU may be directly related to changes in mental state.

Besides, the Diagnostic and Statistical Manual for Mental Disorders-IV (DSM IV) specifically mentions the possibility of adverse reactions, such as hallucinations, with the use of NSAIDs. The symptoms are often related to the dose of the drug and usually disappear when the dose is reduced or discontinued. Many of the studies highlight individuals who already have some mental disorder and decompensated after medication ${ }^{8}$.

In 12 cases, after evaluating the daily patient evolution reports, the study found a worsening of the psychiatric situation after ibuprofen initiation. Unfortunately, the use of algorithms for the validation of adverse events was not applied to support this hypothesis.

\section{CONCLUSION}

This study is the first to increase the risks of using ibuprofen in psychiatric patients and may serve as a warning that, in these cases, ibuprofen-associated therapy may be a risk if used without caution. In the studied population, most of the time, the UBI was being used according to the indications described in the literature. However, regarding safety and dose, the prescription differed from the scientific literature. Although it is considered a safe drug, prescribers must be aware of the risks. The involvement of a clinical pharmacist in a service team can increase the quality of the service provided.

\section{Conflict of interest}

Authors have declared that no conflict of interest exists.

\section{Acknowledgements}

All authors participated equally in the production of the manuscript and the work was carried out according to the ethical requirements of our institution. This study was financed in part by the Coordenação de Aperfeiçoamento de Pessoal de Nível Superior - Brasil (CAPES) - Finance Code 001. Carolina Rosário Dantas was a recipient of a fellowship from the same Agency. 


\section{Ethics approval and consent to participate}

The project was approved by the Research Ethics Committee of the School of Nursing of the Federal University of Bahia (UFBA), Salvador ( $\left.N^{\circ} 1,399,812\right), C A A E$ 51229615.9.0000.5531.

\section{Impact on practice}

The study might contribute to further studies in order to create new policies on the rational use of ibuprofen.

\section{REFERENCES}

1. LUZ, T. C. B. et al. Fatores associados ao uso de antiinflamatórios não esteróides em população de funcionários de uma universidade no Rio de Janeiro: Estudo Pró-Saúde. Rev. Bras. Epidemiol., São Paulo, v.9, n.4, p.514-526, 2006.

2. VILARINO, J. F. et al. Perfil da automedicação em município do Sul do Brasil. Rev. Saúde Pública, São Paulo, v. 32, n.1, p. 43-49, 1998.

3. WOOD, D. M. et al. Fatality after deliberate ingestion of sustainedrelease ibuprofen: a case report. Crit. Care, London, v.10, n.2, p. 44. 2006.

4. ONDER, G. et al. NSAID-related psychiatric adverse events: Who is at risk? Drugs, New York, v.64, n.23, p.2619-2627. 2004.

5. ROSA, A. R et al. Monitoramento da adesão ao tratamento com lítio. Rev. Psiquiatr. Clín., Santiago, v.33, n.5, p. 249-261, 2006.

6. DE ABAJO, F. J.; GARCÍA-RODRÍGUEZ, L.A. Risk of Upper Gastrointestinal Tract Bleeding Associated With Selective Serotonin Reuptake Inhibitors and Venlafaxine Therapy Interaction With Nonsteroidal Anti-inflammatory Drugs and Effect of Acid-Suppressing Agents. Arch. Gen. Psychiatry., Chicago, v. 65, n.7, p. 795-803, 2008.

7. LEITE, S.N.; VIEIRA, M.; VEBER, A.P. Estudos de utilização de medicamentos: uma síntese de artigos publicados no Brasil e América Latina. Cien. Saude Colet., Rio de Janeiro, v. 13, p.793-802. 2008.

8. FOOD AND DRUG ADMINISTRATION (FDA). Nonprescription use of ibuprofen and the risk of gastrointestinal toxicity. 2015. Disponivel em: https://www.fda.gov/ohrms/dockets/ac/02/briefing/3882B2_06 International\%20lbuprofen\%20Foundation.htm. Acesso em: 11 Jan. $201 \overline{6}$.

9. FOOD AND DRUG ADMINISTRATION (FDA). Strengthens warning that non-aspirin nonsteroidal anti - inflammatory drugs (NSAIDs ) can cause heart attacks or strokes. 2016. Disponivel em: https://www.fda.gov/ Drugs/DrugSafety/ucm451800.htm. Acesso em: 10 Nov. 2016.

10. CANADA H. SUMMARY SAFETY REVIEW-Prescription oral ibuprofen (non-steroidal anti-inflammatory drug) - risk of serious heart and stroke adverse events at high doses. 2016. Disponivel em: http://www.hc-sc. gc.ca/dhp-mps/medeff/reviews-examens/ibuprof-eng.php. Acesso em: 10 Nov. 2016

11. EUROPEAN MEDICINES AGENCY (EMA). European Medicines Agency starts review of ibuprofen medicines. Review to evaluate cardiovascular risk with high doses taken over long. 2014. Disponível em: http:// www.ema.europa.eu/ema/index.jsp?curl=pages/news_and_events/ news/2014/06/news_detail_002125.jsp\&mid=WC0b01ac058004d5c1. Acesso em: 10 Nov. 2015.

12. NATIONAL INSTITUTE FOR HEALTH AND CARE EXCELLENCE (NICE) . Osteoarthritis: care and management in adults, Clinical Guideline. Feb. 2014. Disponivel em: http://www.nice.org.uk/guidance/cg177/resources/ guidance-osteoarthritis-pdf. Acesso em: 10 Nov 2016.

13. DUBOIS, R.W. et al. Guidelines for the appropriate use of non-steroidal anti-inflammatory drugs, cyclo-oxygenase-2-specific inhibitors and proton pump inhibitors in patients requiring chronic anti-inflammatory therapy. Aliment. Pharmacol. Ther., Oxford, v.19, p.197-208, 2004.

14. HELIN-SALMIVAARA, A. et al. NSAID use and the risk of hospitalization for first myocardial infarction in the general population: A nationwide case-control study from Finland. Eur. Heart. J., London, v. 27, n.14, p.1657-1663. 2006.

15. FILLINGIM, R.B.; GEAR, R.W. Sex differences in opioid analgesia: clinical and experimental findings. Eur. J. Pain, London, v. 8, n.5, p. 413-425. 2004.

16. DEPARTMENT OF HEALTH. Regulatory A. ARGOM Appendix 5: Guidelines on OTC applications for specific substances. 2012. Available at: https://www.tga.gov.au/publication/argom-appendix-5-guidelinesotc-applications-specific-substances. Acesso em: 06 Dec. 2019.

17. SARKAR, C.; DAS, B.B.P. Analgesic use in dentistry in a tertiary hospital in western Nepal. Pharmacoepidemiol. Drug. Saf., Chichester, v.13, n.10, p.729-33, 2004.

18. AL-KHATEEB, T.H.; ALNAHAR, A. Pain Experience After Simple Tooth Extraction. Oral Maxillofac. Surg., Heidelberg, v. 66, n.5, p.911-917, 2008.

19. WISE, J. Diclofenac and ibuprofen are associated with increased risk of cardiac arrest. BMJ., São Paulo, v.356, p. j1358. 2017.

20. BOMBARDIER, C. Comparison of Upper Gastrointestinal Toxicity of Rofecoxib and Naproxen in Patients with Rheumatoid Arthritis. N. Engl. J. Med., Boston, v. 343, p.1520-1528. 2000.

21. ROSTOM, A.; MOAYYEDI, P.; HUNT, R. Canadian consensus guidelines on long-term nonsteroidal anti-inflammatory drug therapy and the need for gastroprotection: Benefits versus risks. Aliment. Pharmacol. Ther., Oxford, v. 29, p. 481-496, 2009.

22. LAINE, L. Approaches to nonsteroidal anti-inflammatory drug use in the high-risk patient. Gastroenterology, Baltimore, v.120, p.594-606. 2001.

23. WILCOX, C.M. et al. Consensus development conference on the use of nonsteroidal anti-inflammatory agents, including cyclooxygenase-2 enzyme inhibitors and aspirin. Clin. Gastroenterol. Hepatol., Philadelphia, v. 4, p.1082-1089. 2006.

24. CHOU R. et al., Comparative effectiveness and safety of analgesics for osteoarthritis. Agency for Healthcare Research and Quality; September 2006.

25. PATINO, F. G. et al. Nonsteroidal antiinflammatory drug toxicity monitoring and safety practices. J. Rheum., [s.I], v. 30, n.12, p.26802688. 2003.

26. LOKE, Y. K.; TRIVEDI, A. N.; SINGH, S. Meta-analysis: gastrointestinal bleeding due to interaction between selective serotonin uptake inhibitors and non-steroidal anti-inflammatory drugs. Aliment. Pharmacol. Ther., Oxford, v. 27, n.1, p.31-40. 2008.

27. MCKNIGHT, R. F. Lithium toxicity profile: a systematic review and meta-analysis. Lancet, London, v.379, p.721-728. 2012.

28. HASSAN, S. et al. Case report lithium toxicity in the setting of nonsteroidal anti-inflammatory medications. Case Rep. Nephr., Cairo, v. 2013, p.10-11, 2013.

29. PHELAN, K.M.; MOSHOLDER, A.D.; LU, S. Lithium Interaction with the cyclooxygenase 2 inhibitors rofecoxib and celecoxib and other nonsteroidal anti-inflammatory drugs. J. Clin. Psych., [s.I], p. 13281334. 2003.

30. SOARES, D. M. et al. Cyclooxygenase-independent mechanism of ibuprofen-induced antipyresis: The role of central vasopressin V1 receptors. Fundam. Clin. Pharmacol., Paris, v. 25, n.6, p.670-681, 2011. 
Evaluation of ibuprofen prescriptions into a Psychiatric Hospital: regarding safety, indication, and dose

31. WILKINSON, M.F.; KASTING, N.W. Vasopressin release within the ventral septal area of the rat brain during drug-induced antipyresis. Am. J. Physiol., Bethesda, v. 264, n. 6, p.1133-1118. 1993.
32. HEINRICHS, M.; DOMES, G. Neuropeptides and social behaviour: effects of oxytocin and vasopressin in humans. Prog. Brain Res., Amsterdam, v.170, p.337-350, 2008.

Submetido em: $15 / 11 / 2019$

Aceito em: 04/05/2020 